\title{
Investigation of the feasibility of energy piles in Bangkok and their impacts on pile behavior
}

\author{
Apiniti Jotisankasa ${ }^{1, *}$, Korchoke Chantawarangul ${ }^{1}$, Jittavee Sittidumrong ${ }^{2}$, Kachen Thangkhumwong $^{2}$, Phongphat \\ Aowphitak $^{2}$, Pattadol Laohasrisakul ${ }^{2}$, Thiti Chanchayanon ${ }^{1}$, Sineenart Aonkam, and Sakaorat Satayanan \\ ${ }^{1}$ Department of Civil Engineering, Faculty of Engineering, Kasetsart University, Bangkok, Thailand \\ ${ }^{2}$ formerly Department of Civil Engineering, Faculty of Engineering, Kasetsart University, Bangkok, Thailand
}

\begin{abstract}
The energy pile concept, which involves using piles as heat exchanging units for ground source heat pump (GSHP) system, have recently been proposed as a promising way of using shallow geothermal energy resource for cooling buildings to improve energy efficiency and reduce the heat island phenomena in Bangkok Thailand. The power rating of heat exchange capacity of the piles is one of the most important design parameters to consider when evaluating the feasibility of the system. In this study, a full-scale thermal response test was conducted on a spun pile equipped with a single U-loop with the power rating of $60 \mathrm{~W} / \mathrm{m}$, yielding the effective thermal conductivity of $3.3 \mathrm{~W} / \mathrm{m}^{\circ} \mathrm{C}$, while that on steel micro pile yielded the value between 1.49 and $2.01 \mathrm{~W} / \mathrm{m}^{\circ} \mathrm{C}$ with power rating of $10 \mathrm{~W} / \mathrm{m}$. Effects of possible thermal cycles on the compression of Bangkok sand was also investigated in order to evaluate any adverse effects of using piles on pile settlement.
\end{abstract}

\section{Introduction}

Ground-source heat pump (GSHP) and energy pile technologies have been developed mostly in countries of temperate zone [1-3] and just recently receive attentions in other parts of the world including the tropics [4-6]. In the temperate zone, the heating requirement for buildings is normally of a greater importance than the cooling demand and the technology was developed mainly for that purpose. In tropical countries, however, the reverse is true. Many mega cities in the tropics are developing fast, resulting the ever-increasing demand for airconditioning units which is mainly in cooling mode. Figure 1 illustrates this fact. Over the last decade more than 10 fold increase was evidenced in sale of airconditioning unit in Thailand.

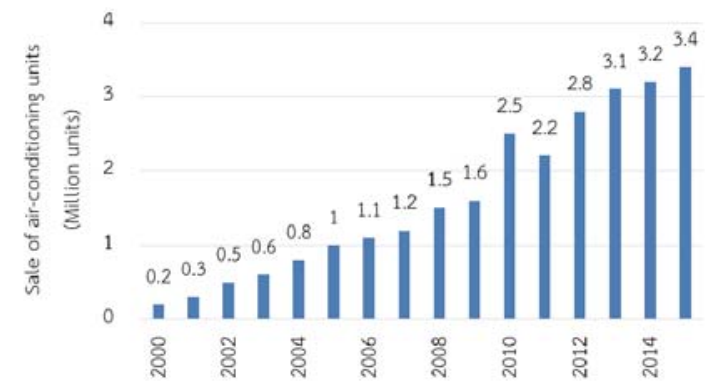

Fig. 1. Statistic of air-conditioning sale units in Thailand according to National Statistical Office

Due to the presence of relatively thick soft clay layer in Bangkok and surrounding provinces (Fig. 2), piles are the most common type of foundation of buildings in the area. In order to alleviate the settlement problem, the pile tips of residential and institutional buildings of 2 to 9 stories in Bangkok are normally embedded in the medium clay layer or the first sand layer depending on pile types (Fig. 3). Typical piezometric profile of Bangkok is also shown in Fig. 3, characterized by the drawdown pressure head in the sand layer which has been historically caused by groundwater pumping. Previous study [5] also indicated that the groundwater flow in this sand layer played an important role in convective heat transfer which improved the efficiency of the ground-source heat pump as the heat exchanger borehole penetrated the sand layer.

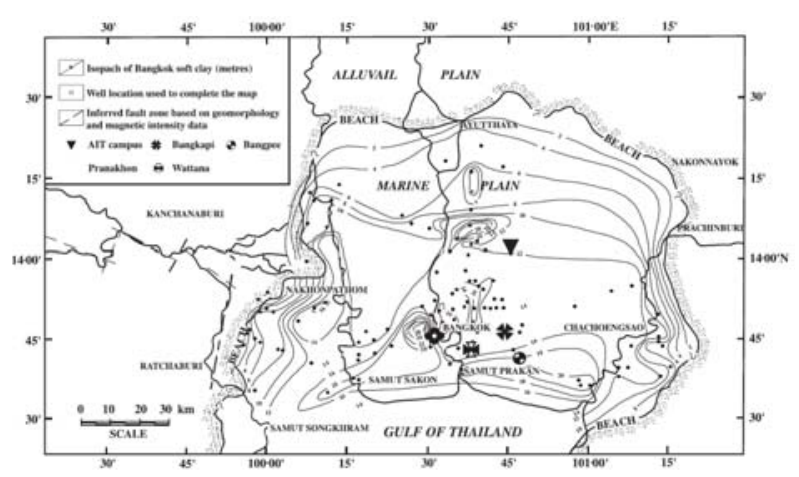

Fig. 2. Contour of thickness of soft Bangkok clay. [7-8]

Even though the results of pioneering research using boreholes as heat exchanger for ground source heat pump in Bangkok were promising, the cost of borehole

\footnotetext{
* Corresponding author: fengatj@ku.ac.th
} 
installation (up to 50m depth) as well as space limitation was a major hindrance to adoption of the GSHP technology in residential building. Given the widespread use of piles in Bangkok, the energy pile concept is an attractive solution to this problem. Nevertheless, the impact of using piles as heat exchangers for GSHP system required careful study to ensure the public that safety of the building was not jeopardized if this technology was adopted as piles will be subjected to thermal cycles during the GSHP operation. This paper reports on the on-going investigation of feasibility of energy pile in Bangkok area and its impacts.

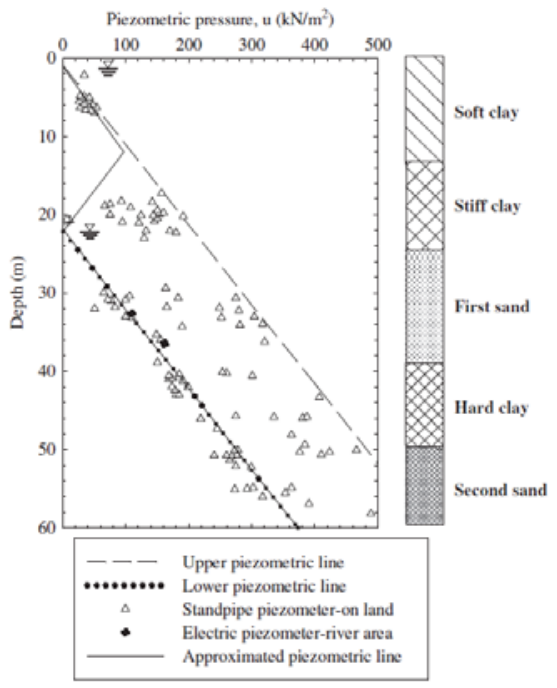

Fig. 3. Typical piezometric pressure and ground profile in Bangkok [9]

\subsection{Previous studies on ground source heat pump system in Thailand}

\subsubsection{Ground temperature}

Yasukawa et al. [10] conducted the groundwater temperature surveys in the Chao-Phraya plain of Thailand, where Bangkok is located. Typical result is shown in Fig. 4. The average ground temperature ranged between $29-30{ }^{\circ} \mathrm{C}$ at the depths between 10 to 50 meters, where piles were likely embedded to. The variation of the ground temperature is compared with the monthly mean maximum and minimum atmospheric temperature as shown in Fig. 5. The mean maximum atmospheric temperature was higher than the ground temperature almost throughout the year except in the month of December. They concluded that underground may be used as cold heat-source even in parts of tropical regions like Bangkok.
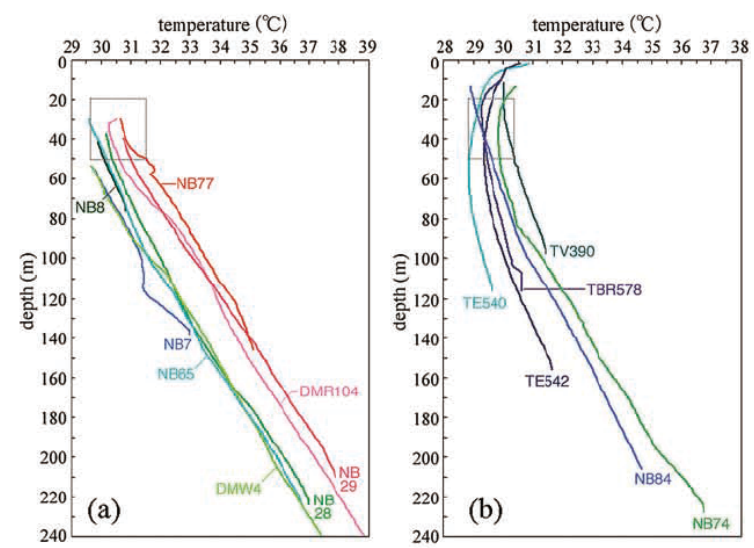

Fig. 4. Typical ground temperature profile in a) Bangkok area b) East Bangkok. [10]

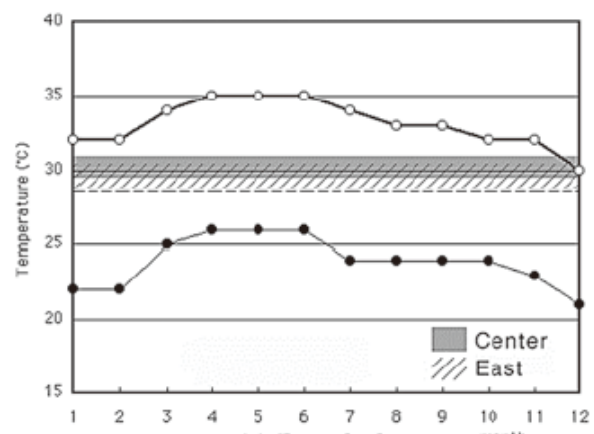

(a) Bangkok

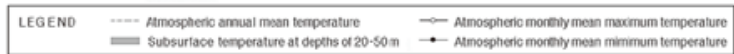

Fig. 5. Typical atmospheric and ground temperature variation in different months in Bangkok. [10]

\subsubsection{Performance of GSHP using horizontal loops and borehole heat exchanger}

Chokchai et al [5], Shimada et al [6] and Takashima et al [11] were amongst the first group of researchers to install and investigate the performance of cooling GSHP system in Bangkok area. Their heat exchangers were horizontal loops buried at 1 meter depth, Takashima et al [11], and vertical loops in boreholes (100 m total length), Chokchai et al [5], Shimada et al [6]. Table 2 summarizes the operating conditions and performance of their systems. In particular, Chokchai et al [5] noted that the groundwater flow in the sand layer at depth between 23 to $41 \mathrm{~m}$ played an important role in removing heat from the ground loop and it was recommended that the borehole heat exchanger installed to this sand layer.

Regarding economy aspect of the GSHP system, Chokchai et al [5] found that the electricity consumption was reduced by about $30 \%$ when using of the GSHP system as compared to normal air-conditioning system. Shimada et al [12] also estimated that, due to its higher installation cost, the advantage of the GSHP would be realized after 14 years of operation. Shimada et al [6] demonstrated that the required numbers of boreholes 
(50m deep) were 24, 4 and 3 for air-conditioned areas of 200,40 , and $25 \mathrm{~m}^{2}$ to achieved $40 \%$ energy saving. Nevertheless, Shimada et al. [6] also acknowledged the budgetary constraint related to the high initial cost of installing the borehole heat exchangers which was still a serious issue in implementation of GSHP technology in practice.

Table 2. Summary of operating conditions and performance of GSHP (Borehole type) from previous studies in Bangkok area

\begin{tabular}{|c|c|c|c|}
\hline $\begin{array}{l}\text { Ground heat } \\
\text { exchanger type }\end{array}$ & $\begin{array}{l}\text { Linear } \\
\text { power } \\
(\mathrm{W} / \mathrm{m})\end{array}$ & $\begin{array}{l}\text { Operating/Testing } \\
\text { condition }\end{array}$ & Reference \\
\hline $\begin{array}{c}\text { Horizontal } \\
\text { loop }-32 \mathrm{~mm} \\
\text { outer diameter, } \\
200 \mathrm{~m} \text { total } \\
\text { length, } \\
1 \mathrm{~m} \text { deep }\end{array}$ & NA & $\begin{array}{c}\text { Flow rate }=15 \\
1 / \mathrm{min} ; \\
\text { Inlet temperature } \\
\text { (into ground) }=35- \\
39^{\circ} \mathrm{C} ; \\
\text { Outlet temperature } \\
\text { (from the ground) }= \\
32-35^{\circ} \mathrm{C} ; \\
\mathrm{COP}=3-4 \\
\text { (approximate) }\end{array}$ & [11] \\
\hline $\begin{array}{c}2 \text { Vertical } \\
\text { boreholes with } \\
\text { single u-tube, } \\
32 \mathrm{~mm} \text { outer } \\
\text { diamter (50 m } \\
\text { depth each) }\end{array}$ & $\begin{array}{l}20-40 \\
W / m\end{array}$ & $\begin{array}{c}\text { Rated cooling } \\
\text { capacity }=4000 \mathrm{~W} ; \\
\text { Flow rate }=15 \\
1 / \mathrm{min} ; \\
\text { Inlet temperature } \\
\text { (into ground) }=36 \\
{ }^{\circ} \mathrm{C} ; \\
\text { Outlet temperature } \\
\text { (from the ground) }= \\
34.2^{\circ} \mathrm{C} ; \\
\mathrm{COP}=4.38 \\
\text { (measured) }\end{array}$ & {$[5,6]$} \\
\hline
\end{tabular}

\section{Development of energy pile in Thailand}

\subsection{Small scale physical model}

As the potential of GSHP technology for cooling-mode air-conditioning was demonstrated in Bangkok, the prospect of using piles as heat exchangers, i.e. energy piles, was also investigated at Kasetsart University. By using the piles, which are already needed for load bearing purpose, as heat exchanger, the budgetary constraint of GSHP would be reduced. A number of studies from around the world have been conducted, that have focused on development of scale-model energy piles, e.g. [15-17], and provided a better insight into energy pile behaviour. Jotisankasa et al. [4] reported on a study using a model reinforced-concrete energy pile $(15 \mathrm{~cm}$ in diameter and $60 \mathrm{~cm}$ in height) embedded with PE plastic tube (6 mm outer-diameter and thickness of 1 $\mathrm{mm}$ ) as heat absorber having a total embedded length of 12 meter inside the concrete pile. The model pile was used to investigate the general heat transfer character of energy piles in various media, including water, air and Bangkok clay slurry. The amounts of heat transfer for energy pile in contact with water, and with clay were nearly the same, and nearly twice that of pile with air. The power rate was found to be $27.8 \mathrm{~W} / \mathrm{m}$ of pile length which was a reasonable number. Nevertheless, the test duration was only of limited time (a few hours) and of much smaller size than actual pile, thus may not be applicable to true-scale pile operation.
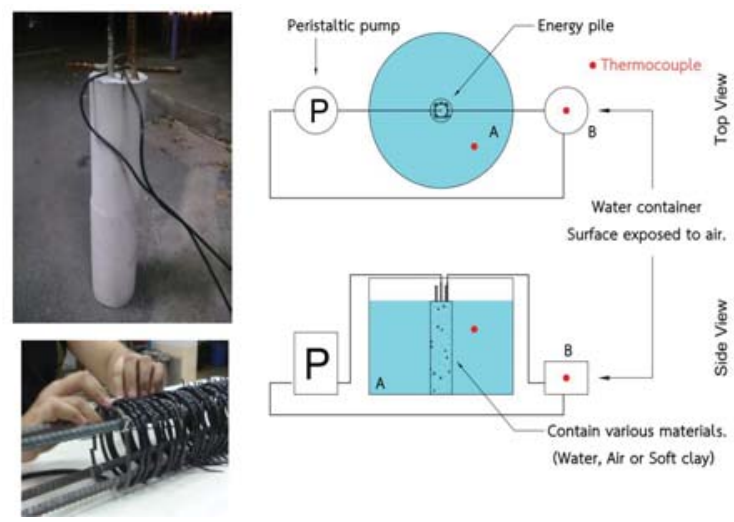

Fig. 6. A small scale physical model of energy pile and simple heat transfer test

\subsection{Selection of pile types for ground heat exchangers}

The pile types which are considered to be readily applicable as energy pile in Thailand are hollow precast displacement piles, namely steel tube pipe (so-called micro-pile) (Fig. 7a\&b), spun pre-stressed concrete pile (Fig. 7c\&d), and screw steel pile (Fig. 7e\&f). The cost associated with modifying these piles as heat exchanger is only the plastic pipes, fitting valves, installation and supervision. The installation is relatively straightforward with minimal interference to usual construction activities. The typical embedment depths of the piles for residential house (with 1 to 3 stories), and building with less than 10 stories) in Bangkok are around 15 to 25 meters, and the pile tips are likely in the stiff clay and sand layers respectively (Fig. 3). For a given pile size, the steel pipe and screw piles have larger inner hole than the spun concrete pile. The spun concrete pile is normally open-ended and consequently the soil plug could reduce the available length for plastic tube insertion.

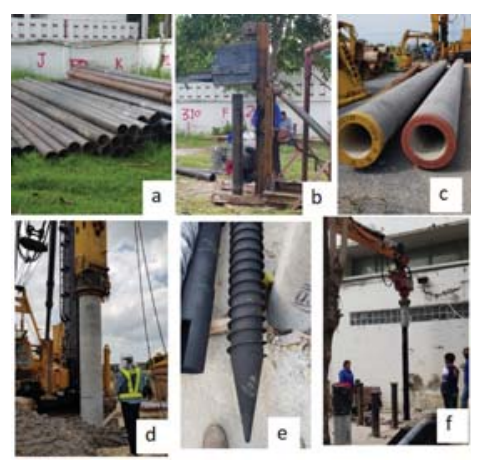

Fig. 7. Displacement piles considered useable as energy piles, $(a, b)$ steel tube pipe (so-called micro-pile); (c, d) spun prestressed concrete pile and (e and f) screw steel pile 
Bored piles are also commonly used in Bangkok. However, given the more complexities involved with installation of plastic HDPE loop with the reinforcing steel cage, the modification bored pile as heat exchanger will be carried out at a later stage.

\subsection{Thermal response test of a concrete spun pile}

One of the first thermal response tests (TRT) on energy pile carried out in Thailand was on a square spun pile $\left(40 \times 40 \mathrm{~cm}^{2}\right.$ with $25 \mathrm{~cm}$ diameter circular inner hole) using a single U-tube loop ( 32 outer diameter and $25 \mathrm{~mm}$ inner diameter). There was no load applied on the pile during the test. The pile was embedded to $22 \mathrm{~m}$ depth with thermal active length of $14 \mathrm{~m}$, where the HDPE loop was installed. The inner hole of the pile was filled with water during the test. Fig. 8 shows that the lower end of the u-tube loop penetrated into the sand layer by about 1 meter deep. This facilitated the additional removal of heat via convection due to ground water flow in the sand layer. The area where the test was conducted, i.e. Pathumthani province, was known to have active ground water pumping activities for various kinds of industrial usages and downward seepage and pore pressure drawdown was expected though it was not directly measured at this site.

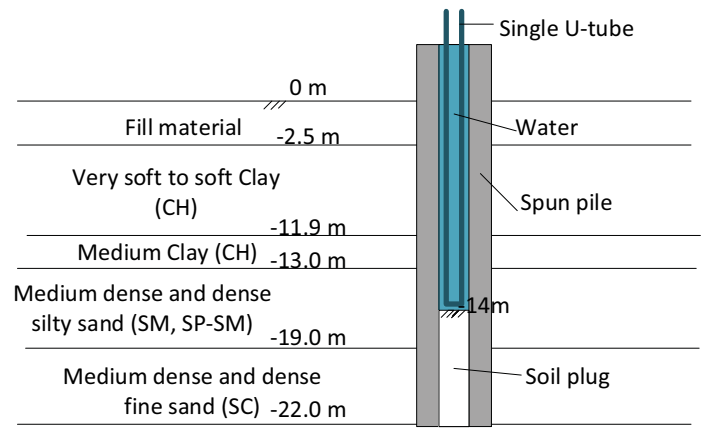

Fig. 8. Layout of the spun pile used for Thermal response test (not-to-scale)

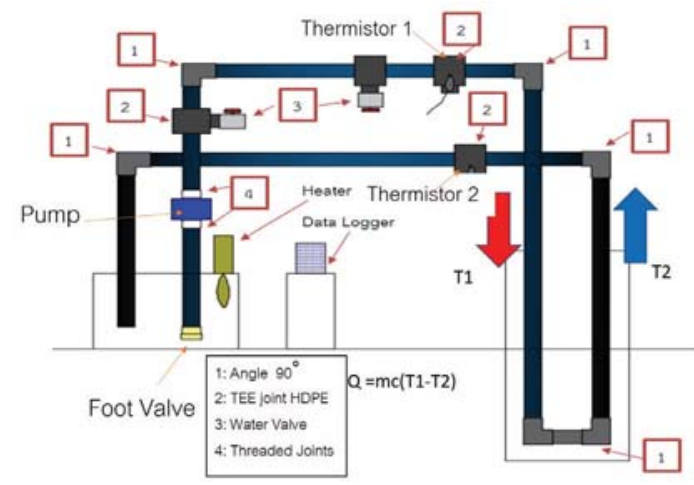

Fig. 9. Schematic of the simple equipment for thermal response test on spun concrete pile
Typical TRT result is shown in Fig. 10. The calculated linear power was $60.4 \mathrm{~W} / \mathrm{m}$. Since the test was run for only about 7.5 hours, it was acknowledged this linear power could decrease further if the test were continued longer. The effective thermal conductivity, $\lambda$, was 3.32 $\mathrm{W} / \mathrm{m}^{\circ} \mathrm{C}$, as calculated using the measured temperature inside the pile and the T-ln $t$ approach. This measured $\lambda$ value is higher than suggested values of thermal conductivities of typical soils in the literature [13]. It is thought to be due to the influence of groundwater pumping in the sand layer that cause this relatively high value of $\lambda$.

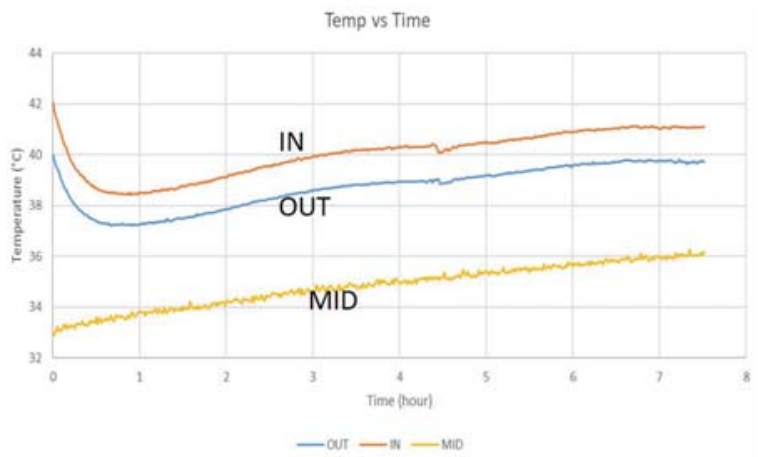

Fig. 10. Typical result of thermal response test on a spun concrete pile

\subsection{Energy piles for a residential house in Bangkok}

The first set of energy piles were then constructed for the first author's residential house in Bangkok. In total, 13 steel pipe piles (152mm diameter) was equipped with single U-tube $(32 \mathrm{~mm}$ outer diameter and $25 \mathrm{~mm}$ inner diameter). The piles were about 17.5 meter long and their toes were located in either the stiff clay or clayey sand. This soil layer was expected to be of lesser groundwater seepage than in the sand layer in Pathumthani province where the spun pile was tested earlier. The thermo-active length of the pile was about $17.4 \mathrm{~m}$ (i.e. $10 \mathrm{~cm}$ less than the total pile length). The inner hole of the pipe was filled with concrete after the HDPE pipe was installed. Fig. 11 shows the installation of the energy pile on-site.

The heat exchanger consisted of two loops $(1 \& 2)$ connected in parallel. Loop 1 involved 6 piles connected in series, while Loop 2 involved 7 piles also in series with three thermistors installed in the concrete inside the pile at around 8 meter depth. A preliminary thermal response test using an average heat power of 10.7 and $9.3 \mathrm{~W} / \mathrm{m}$ was carried out in Loop 1 and 2 respectively, yielding results of inlet and outlet temperature and temperature increase inside the pile with time as shown in Fig. 12 and 13. The calculated effective thermal conductivity, $\lambda$, was 2.01 and $1.49 \mathrm{~W} / \mathrm{m}^{\circ} \mathrm{C}$ for Loop 1 and 2 respectively. These values are lower than that obtained from test on spun concrete pile explained earlier. The depth of the pile and seepage in the sand layer are expected to play an important role on this difference, though more studies are still required. 


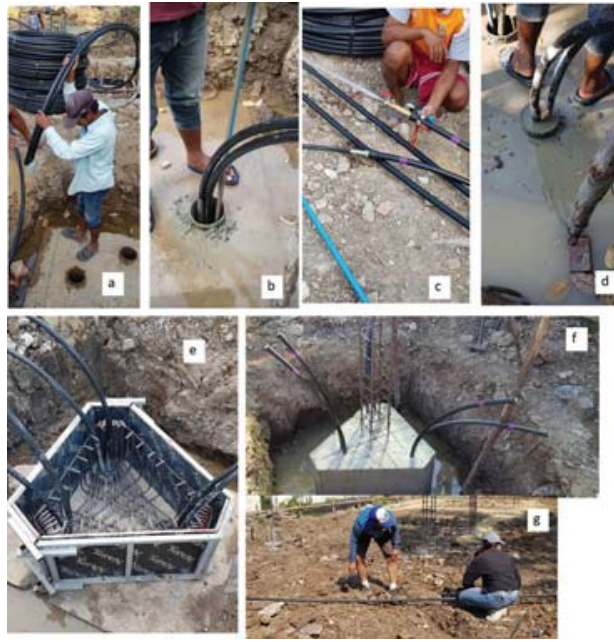

Fig. 11. Installation of HDPE U-tube loops in the steel pipe piles of a residential house in Bangkok
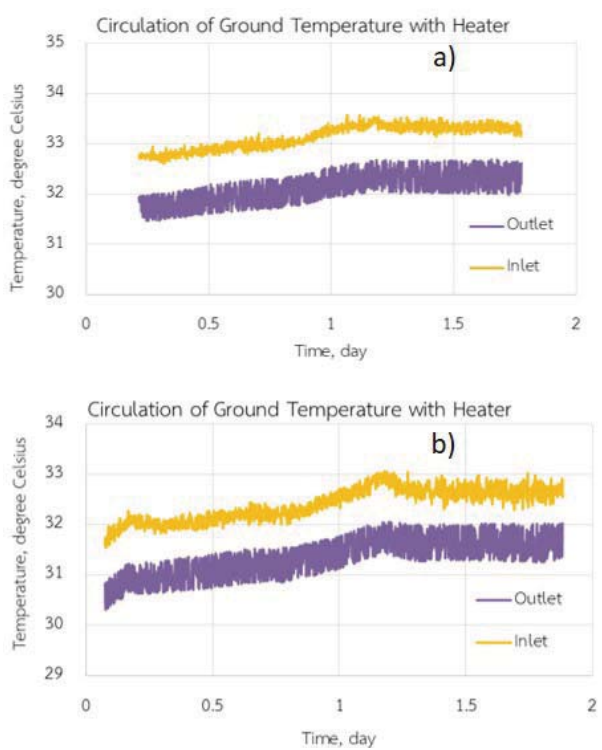

Fig. 12. Inlet and outlet temperature during thermal response test on steel pipe piles of a residential house in Bangkok, a) Loop 1, b) Loop 2

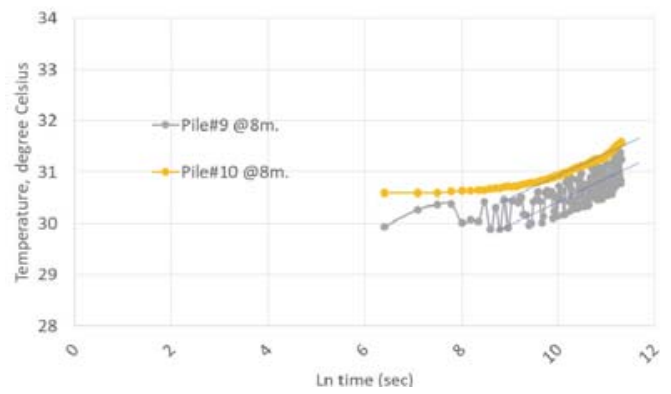

Fig. 13. Typical temperature increase inside a steel pipe energy pile during a thermal response test

\section{Investigation of thermal cycle impact on compression of Bangkok sand}

It was expected that operation of energy pile GSHP in Bangkok area would involve numerous cycles of temperature, due to the nature of air-conditioning usage in this climate. The influence of temperature cycles on pile settlement was needed to check if there was any adverse effect especially in the Bangkok sand layer where the pile toe was located and the stress level was high. Therefore, the effect of numerous thermal cycles on the volumetric behaviour of saturated Bangkok sand was investigated using a double thermal oedometer test that incorporates a temperature control system [14].

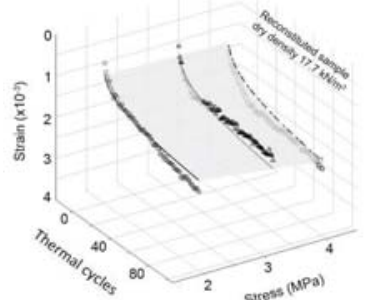

(a)

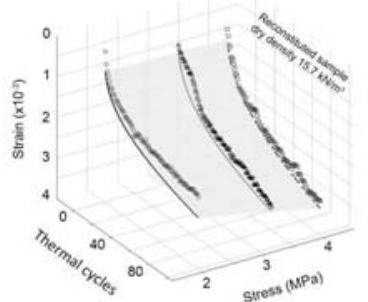

(c)

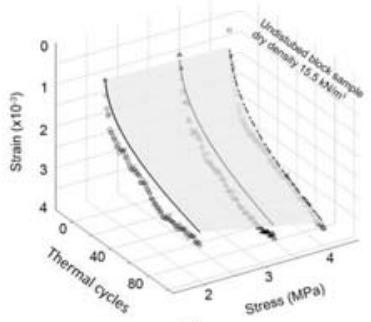

(e)

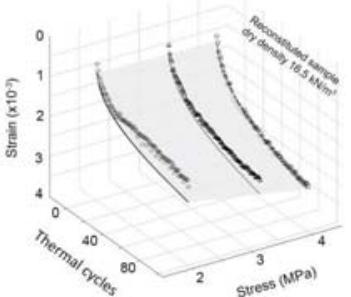

(b)

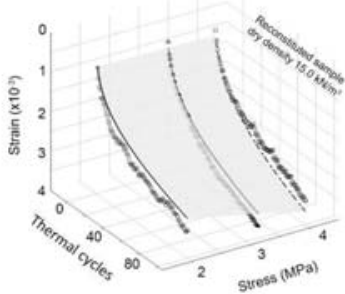

(d)
Fig. 14. Constitutive surfaces of thermal cycle-induced strains for: (a) reconstituted sand $(\mathrm{Dr}=98 \%)$; (b) reconstituted sand $(\mathrm{Dr}=70 \%) ;(\mathrm{c})$ reconstituted sand $(\mathrm{Dr}=50 \%) ;(\mathrm{d})$ reconstituted sand $(\mathrm{Dr}=30 \%)$; and $(\mathrm{e})$ undisturbed sand $(\mathrm{Dr}=$ $44 \%)($ MLR $=$ Multiple-linear regression analysis $)[14]$

The experiments were performed at three different vertical stresses $(2.007,3.211$ and $4.014 \mathrm{MPa})$ on a reconstituted sand having different initial densities as well as an undisturbed sand from a block sample collected from a depth of $32 \mathrm{~m}$ in Bangkok. Up to 100 heating-cooling cycles (each involving $28-50-28^{\circ} \mathrm{C}$ steps with a frequency of 1 cycle per hour) were simulated in the oedometer. The strains induced by thermal cycles were found to correlate with the number of cycles using a power law. The maximum thermal cycle-induced strain was 0.0037 (equivalent to a change in relative density of 
$1.7 \%$ ) in the case of loose reconstituted sand (initial relative density of $30 \%$ ) after 100 thermal cycles.

Typical results are shown in Fig. 14. Such relationships between thermal cycle-induced strain and the relative density of the sand could be used to estimate the likely amount of settlement between piles due to heat cycles in the long term. Nevertheless, it is acknowledged that pile settlement due to heat cycles resulting from energy pile usage is a complex phenomenon, requiring more rigorous numerical tool to investigate in a more precise manner [13]

\section{Conclusions}

Given the widespread use of piles for buildings in Bangkok, the energy pile concept is an attractive solution to high energy demand in the air-conditioning power consumption sector in the tropics. The power rating of heat exchange capacity of the piles is one of the important design parameters to consider when evaluating the feasibility of the system. In this study, a full-scale thermal response test was conducted on a spun pile equipped with a single U-loop with the power rating of $60 \mathrm{~W} / \mathrm{m}$, yielding the effective thermal conductivity of $3.3 \mathrm{~W} / \mathrm{m}^{\circ} \mathrm{C}$. Another test on steel micro pile yielded the conductivity value between 1.49 and $2.01 \mathrm{~W} / \mathrm{m}^{\circ} \mathrm{C}$ with power rating of about $10 \mathrm{~W} / \mathrm{m}$. Effects of possible thermal cycles on the compression of Bangkok sand was also investigated in a double thermal oedometer tests in order to evaluate any adverse effects of using piles on pile settlement. The strains induced by thermal cycles were found to correlate with the number of cycles using a power law.

The authors are grateful to the financial supports provided by Faculty of Engineering, Kasetsart University for this research. Ta-tech Co., Ltd, Kemrex Co., Ltd and Pathumthani Concrete Co., Ltd, (PACO) are also thanked for providing the supports for conducting the thermal response tests on their piles.

\section{References}

1. H. Brandl, Energy foundations and other thermoactive ground structures, Geotechnique. 56(2), 81122 (2006)

2. L. Laloui, A. Di Donna, Energy Geostructures. (2013)

3. H. Abuel-Naga, A.M.I. Raouf, M.I.N. Raouf, A.G. Nasser, Energy piles: current state of knowledge and design challenges. Environ Geotech. 1-16. (2014)

4. A. Jotisankasa, J. Sittidumrong, K. Chantawarangul, Preliminary investigation of energy piles in soft Bangkok clay. Proc. of the 1st Int. Conf. on GeoEnergy and Geo-Environment, Hong Kong. (2015)

5. S. Chokchai, S. Chotpantarat, I. Takashima, Y. Uchida, A. Widiatmojo, K. Yasukawa, P. Charusiri. A pilot study on geothermal heat pump (GHP) use for cooling operations, and on ghp site selection in tropical regions based on a case study in Thailand. Energies, 11(9) (2018)
6. Y. Shimada, Y. Uchida, I. Takashima, S. Chotpantarat, A. Widiatmojo, S. Chokchai, P. Charusiri, H. Kurishima, K. Tokimatsu, A study on the operational condition of a ground source heat pump in Bangkok based on a field experiment and simulation. Energies, 13(274) (2020)

7. P. Nutalaya, J.L. Rau, Bangkok: the sinking metropolis. Episode, 4, 3-8 (1981)

8. S. Horpibulsuk, S. Shibuya, K. Fuenkajorn, W. Katkan, Assessment of engineering properties of Bangkok clay. Can. Geotech. J. 44, 173-187 (2007)

9. C. Surarak, S. Likitlersuang, D. Wanatowski, A. Balasubramaniam, E. Oh, H. Guan, Stiffness and strength parameters for hardening soil model of soft and stiff Bankok clays. Soils. Founds. 52(4), 682697 (2012)

10. K. Yasukawa, Y. Uchida, N. Tenma, Y. Taguchi, H. Muraoka, T. Ishii, J. Suwanlert, S. Buapeng, T.H. Nguyen, Groundwater temperature survey for geothermal heat pump application in tropical Asia. Bull. Geol. Surv. Jpn. 60, 459-467 (2009)

11. I. Takashima, K. Yasukawa, Y. Uchida, M. Yoshioka, K. Won-in. A geothermal heat pump system in Bangkok, Thailand. Proc. of the 9th Asian Geothermal Symposium. 96-101 (2011)

12. Y. Shimada, H. Kurishima, Y. Uchida, Environmental and cost evaluation of introduction of ground source heat pump in Bangkok, Thailand. In Proc. of the Grand Renewable Energy 2018 Int. Conf. and Exh. Yokohama, Japan (2018)

13. L. Laloui, A. Rotta Loria. Analysis and Design of Energy Geostructures, 1st Edition, Academic Press (2020)

14. J. Sittidumrong, A. Jotisankasa, K. Chantawarangul. Effect of thermal cycles on volumetric behavior of Bangkok sandGeomechanics for Energy and the Environment. 20, (2019)

15. F. Loveridge, J.S. McCartney, G. A. Narsilio, M. Sanchez, Energy geostructures: A review of analysis approaches, in situ testing and model scale experiments. Geomechanics for Energy and the Environment. 22, (2020).

16. N. Yavari, A.M. Tang, J.M. Pereira, G. Hassen, Mechanical behaviour of a small-scale energy pile in saturated clay. Geotechnique, 66(11), 878-887. (2016).

17. R. Zhao, A.K. Leung, D. Vitali, J.A. Knappett, Z. Zhou, Small-scale modeling of thermomechanical behavior of reinforced concrete energy piles in soil. Journal of Geotechnical and Geoenvironmental Engineering, 146(4) (2020). 